\title{
PECEN Publications in the Field of Biological Sciences: Present and Future
}

\author{
Silvio Felipe Barbosa Lima ${ }^{1,2}$
}

(1) Universidade Federal de Campina Grande, Centro de Formação de Professores, Unidade Acadêmica de Ciências Exatas e da Natureza, Rua Sérgio Moreira de Figueiredo, S/N, Casas Populares, Cajazeiras 58900-000, Paraíba, Brasil. E-mail: sfblima@gmail.com, silvio.lima@ufcg.edu.br

(2) Universidade Federal da Paraíba - Campus II, Centro de Ciências Agrárias, Departamento de Ciências Biológicas, Programa de Pós-Graduação em Biodiversidade, Cidade Universitária, Areia 58397-000, Paraíba, Brazil.

Lima S.F.B. (2017) PECEN Publications in the Field of Biological Sciences: Present and Future. Pesquisa e Ensino em Ciências Exatas e da Natureza, 1(2): 84-85.

Biological Sciences is the discipline that studies the most diverse aspects of microscopic and macroscopic life forms on earth. This vast field of studies enables biologists to follow numerous paths according to their professional interest.

Biological Sciences has made rapid advances in Biochemistry, Biophysics, Biotechnology, Botany, Cell Biology, Ecology, Ethnobiology, Evolutionary Biology, Genetics, Immunology, Mycology, Microbiology, Morphology, Parasitology, Physiology and Zoology. In some cases, the expansion of different fields of Biological Sciences is tied to the crisis of biodiversity and environmental problems, such as the extinction of species, the introduction of invasive exotic species, increasing habitat loss and degradation, the overexploitation of natural resources, pollution, diseases and human-induced climate change.

In 2017, Pesquisa e Ensino em Ciências Exatas e da Natureza/Research and Teaching in Exact and Natural Sciences (PECEN) received 28 manuscripts for evaluation and published 18 papers, all related to the field of Biological Sciences. An analysis of the papers published in year shows that the field of Zoology (branch of Biology that studies the animal kingdom) has been the flagship of publications with 7 papers so far. Among the contributions within Zoology published in PECEN are papers involving the following sub-fields of knowledge: (2) Morphology of Recent Groups; (4) Taxonomy of Recent Groups; and (3) "ecological interactions" phenomenon and object of study also in the field of Ecology. In 2017, PECEN also published important contributions in the fields of Ecology (2), Environmental Sciences (1), Health and Biological Science (1), Mycology (2) and Science Teaching (2).

Contributions in the fields of biodiversity and science teaching will undoubtedly continue to play an important role in the scientific production of PECEN in both qualitative and quantitative terms. However, given the vast field of Biological Sciences, we expect a substantial increase in the number of publications on the most diverse subjects in 2018.

It is important to emphasize that PECEN is a multidisciplinary journal that receives contributions from diverse fields, such as Agrarian, Biomedical, Chemical, Earth, Environmental, Health and Exact and Natural Sciences. The fundamental mission is to strengthen multidisciplinary publications through scientific and theoretical-methodological studies as well as thematic literature reviews. Regardless of the number of submissions, the main factor for publication in PECEN is the importance and quality of the contributions. 
I would like to take the opportunity to congratulate all authors who published in Volume 1 (Number 1-2) of PECEN and thank those who made contributions in the terms of scientific/academic, teaching and social contexts. I would also like to thank the associate editors for their participation in the evaluation process of the manuscripts. Lastly, let me take the opportunity to invite students, teachers and readers to participate in upcoming editions of PECEN through the submission of manuscripts on the most diverse areas of sciences.

\section{EDITORIAL TEAM}

\section{EDITORS-IN-CHIEF}

Dr. Carlos Davidson Pinheiro;

M. Sc. Eudes Leite de Lima;

Dr. Heydson Henrique Brito da Silva;

Dr. Silvio Felipe Barbosa de Lima;

\section{EDITORIAL AND SCIENTIFIC BOARD}

Dra. Albaneide Fernandes Wanderley;

Dr. Carlos Davidson Pinheiro;

M. Sc. Edilson Leite da Silva;

M. Sc. Eudes Leite de Lima;

Dr. Fernando Antônio Portela da Cunha;

M. Sc. Francisco Carlos Pinheiro da Costa;

M. Sc. Gustavo de Alencar Figueiredo;

Dr. Heydson Henrique Brito da Silva;

Dr. João Maria da Silva;

Dr. José Deomar de Souza Barros;

Dra. Letícia Carvalho Benitez;

Dra. Mirleide Dantas Lopes;

Dr. Paulo Roberto de Medeiros;

Esp. Rosana Ferreira de Alencar;

Dr. Silvio Felipe Barbosa de Lima;

\section{SECTION SCIENTIFIC EDITORS}

Dra. Albaneide F. Wanderley (Chemistry); Dr. Carlos Davidson Pinheiro (Chemistry); Dr. Fernando A. Portela da Cunha (Chemistry); Dr. Luciano Leal de Morais Sales (Chemistry); M. Sc. Edilson Leite Silva (Computer Science); M. Sc. Eudes Leite de Lima (Mathematics); M. Sc. Franciélia L. de Sousa (Mathematics); Dr. Douglas Fregolente (Physics);

M. Sc. Gustavo de Alencar Figueiredo (Physics); Dr. Heydson Henrique Brito da Silva (Physics); Dra. Mirleide Dantas Lopes (Physics);

M. Sc. Francisco Carlos P. Costa (Biology);

M. Sc. Hugo da Silva Florentino (Biology);

Dra. Letícia Carvalho Benitez (Biology);

Dr. Paulo Roberto de Medeiros (Biology);

Esp. Rosana Ferreira Alencar (Biology);

Dr. Silvio Felipe Barbosa de Lima (Biology);

Dr. Udson Santos (Biology);

\section{ASSOCIATE EDITORS}

Dr. Alessandre Pereira Colavite (UFPB/DSE);

Dr. Alexandre Campos (UFCG/CCT/UAF);

Dra. Antonia Arisdélia A. Feitosa (UFPB/DSE);

M. Sc. Arielson Santos Protázio (UFRB/CCAAB);

Dr. Carlos Alexandre Borges Garcia (UFS/DQI);

Dra. Daniela Franco Carvalho (UFU/ICB/IB);

Dra. Elisabete Maria Zanin (URI/FURI);

Dr. Etielle Barroso de Andrade (IFPI);

Dra. Eugenia Jacira Bolacel Braga (UFPel/IB);

Dr. Felipe Wartchow (UFPB/DSE);

Dr. Gilberto Gonçalves Rodrigues (UFPE/CCB);

Dr. Hugo Fernandes-Ferreira (UECE/DSE);

Dr. Joaquim Evêncio Neto (UFRPE/DMFA);

Dr. Jose Ricardo Miras Mermudes (UFRJ/IB);

Dr. Leonardo Esteves Lopes (UFV/CEDAF);

Dr. Marcelo Fulgêncio Guedes Brito (UFS/DB);

Dr. Marcelo V. Fukuda (UFJF/ICB/DZOO);

Dr. Marcio Bernardino da Silva (UFPB/DSE);

Dra. Maria do S. Ferreira da Silva (UFS/DGE);

Dra. Marla Ibrahim U. de Oliveira (UFS/DBI);

Dr. Martin Lindsey Christoffersen (UFPB/DSE);

Dr. Mauro de Melo Júnior (UFRPE/DB);

Dra. Michela Borges (UNICAMP/IB/MZ);

Dr. Pablo Ariel Martinez (UFS/CCBS/DBI);

Dr. Patrício Borges Maracajá (UFCG/CCTA);

Dr. Paulo Henrique R. Peixoto (UFPE/CAA);

M. Sc. Raul Azevedo (UFCA/CCAB);

Dra. Rita de Cássia M. C. Rodriguez (UFPel/IB);

Dr. Rodrigo Giesta Figueiredo (UFES/CCENS);

Dr. Samuel Vieira Brito (UFMA/CCAA);

Dr. Saulo Pomponet Oliveira (UFPR/DMAT);

Dr. Sérgio André Fontes Azevedo (UFPB/DF);

Dra. Thatyara Freire de Souza (UFERSA/CMPF);

Dr. Wedson de Medeiros S. Souto (UFPI/CCN);

ASSISTANT AND PRODUCTION EDITORS

Sr. Danilo Sousa de Freitas (UFCG);

Sr. Emanuel Evaristo de Sousa (UFCG);

Sr. Gustavo Tavares de Abreu (UFCG);

Sr. José Mateus Sarmento (UFCG);

Dr. Onireves Monteiro de Castro (UFCG);

OPERATIONAL TECHNICAL SUPPORT AND GRAPHIC DESIGNER

Sr. Antonio Lourenço de Araújo Filho;

Sr. Delio Jackson Dantas Duarte; 